\title{
The Role of Corporate Governance to the Relationship Between Income Smoothing, Dividend, Growth and Earnings Informativeness
}

\author{
Vinola Herawaty*, Anggun Prabowo \\ Faculty of Economics and Business \\ Universitas Trisakti \\ Jakarta, Indonesia \\ *vinola.herawati@trisakti.ac.id
}

\begin{abstract}
The objective of this empirical study is to analyse the influence of dividend policy, company growth, and income smoothing to earnings informativeness on manufacturing companies listed on Indonesia Stock Exchange in 2016 - 2018. Earnings informativeness represents market reaction of price change to company's unexpected earnings which is proxied by earnings response coefficient. This study also uses corporate governance measured by the ASEAN Corporate Governance Scorecard as moderating variable. The samples used in this research were 129 originating observations from 47 manufacturing companies listed on the Indonesia Stock Exchange during period of 2016 to 2018. The results show that income smoothing has a positive influence to earnings response coefficient while dividend policy, and company growth do not have positive influences to earnings response coefficient. CG strengthens the influence of income smoothing to earnings response coefficient. However, CG does not moderate the influence of dividend policy and company growth to earnings response coefficient.
\end{abstract}

Keywords-corporate governance, dividend policy, earnings informativeness, company growth, income smoothing

\section{INTRODUCTION}

The Indonesian capital market has experienced rapid development and progress. This has had a positive impact, one of which is the increasingly active role of the community. The fact can be proven from year to year the number of issuers continues to grow and increase. The increase in the number of issuers has a positive impact on the number of transaction volumes that continue to increase, as well as the value of trading shares on the Indonesia Stock Exchange. The Composite Stock Price Index from 2012 to 2018 experienced a significant increase especially in the period of 2017 [1], a significant increase in the combined share price over the last few periods, then this will have an impact on the market return value represented by the Composite Stock Price Index, which is the market return then it will be used to see the abnormal return value.
Earnings response coefficient (ERC) is used to measure the extent of abnormal securities market returns in response to unexpected indicators of earnings reported by securities issuing companies [2]. A low earnings response coefficient indicates that the announced earnings are not too informative for an investor to make an investment decision. Earnings response coefficient is important and useful for conducting fundamental analysis in calculating the actual value of company shares using financial statement data that has been presented by the company [3]. This is used as a basis for investor evaluations to determine market reactions to earnings information on the company's stock price.

In determining market response using ERC, there are several stages: first, by calculating cumulative abnormal returns, secondly by calculating unexpected earnings and the last stage by revising the results of the calculation of cumulative abnormal returns and unexpected earnings. ERC was proxied using CAR (Cumulative Abnormal Return) which was regressed with the EU (Unexpected Earnings) which represented the company's accounting earnings [4].

Company growth is a condition in which the condition of the company that continues to grow from one period to the next, where the source of growth is obtained from investor capital or internal funding sources, namely free cash flow. Investors will respond more to companies that are experiencing growth, so companies that have the opportunity to grow larger will have a higher earnings response coefficient. This condition shows that the greater a company has the opportunity to grow, the higher the company to earn profits in the future [5].

Investors use information on corporate earnings to make investment decisions [6]. Research indicates that there is an inherent relationship between the level of corporate earnings with the value of company shares, so it can be said that an increase in corporate income will reflect the level of increase in stock prices and vice versa. The magnitude of the relationship and influence between accounting earnings and responses from investors is shown using earnings response coefficient. This study is a modification research of Adonis [7] by changing and 
adding independent variables: Dividend policy and company growth [8]. This happens because it is suspected that investors are more likely to have companies that have dividends and company growth. As well as the difference in this study with previous studies by adding control variables with company size [9] and capital structure [10].

\section{LITERATURE REVIEW}

Signalling theory basically explains the importance of information presented by companies to decisions in investments that come from externally. Information released by the company is a description of the description or notes from the past, present or future of the condition of a company [11]. Another grand theory is agency theory [12]. Agency theory deals with contractual relationships between company members. Agency theory is the agency relationship arising from a contract between the owner (principal) and the manager (agent) in providing services and then delegating decisionmaking authority.

An efficient capital market always reflects all new and also relevant information, while new information cannot be predicted early [11]. Thus, the process of changing the price of securities on the exchange becomes random and cannot be predicted in advance. There are three forms of efficient markets which are often known as efficient market hypothesis [13]. The three forms of efficient markets are the weak market hypothesis in the form of a weak (weak form of the efficient hypothesis), the efficient market hypothesis in the form of half strong (semistrong form of the efficient market hypothesis), and the last is the efficient market hypothesis in the strong form (strong form of the efficient market hypothesis).

\section{A. Effect of Income Smoothing on Earnings Response Coefficient}

Income smoothing which is part of earnings management actions in which a management condition intervenes in the process of preparing financial statements. Management of companies that do income smoothing actions indirectly responded positively by the market. The higher the level of income smoothing, the higher the market reaction will be proxied by cumulative abnormal return. Market reaction to companies that do income smoothing is different from companies which does not do income smoothing [14,15].

H1: Income smoothing has a positive effect on earnings response

\section{B. Effect of Company Growth on Earnings Response Coefficient}

Investors have expectations and motivation in investments made not only to produce long-term earnings but also have the motivation to obtain capital gains. In accordance with agency theory that in general an agent can be said to be a company controller, of course, having a lot of information about the current condition of the company. Therefore, agents who gain the trust of the principal should be able to carry out their duties and functions well and are directed and there are no deviations related to the company's objectives. With a system that runs well, it is hoped that it will produce a good company growth rate. Factors regarding the growth opportunities of a company are generally considered by investors who have a long-term perspective in order to produce yields from the investments they do $[16,17]$.

H2: Company growth has a positive effect on earnings response coefficient

\section{Effect of Dividend Policy on Earnings Response Coefficient}

Naturally, investors inclined to like higher dividend when the company has a high operating profits. Because if the company generates high profits means the company has the ability to pay large amounts of dividends which indicate that the company has good financial flexibility. Then one indicator of investors in measuring and being considered to determine investment decisions is dividend policy [8]. Dividend is a good signal for investors [18] that can be reflected in stock price.

H3: Dividend policy has a positive effect on earnings response coefficient

\section{Moderating Effect of Corporate Governance on the Relation Between Income Smoothing and Earnings Response Coefficient}

Market response to companies that do income smoothing practices is different from companies that do not do levelling actions [14]. This will indicate investors to present that the company has relatively stable earnings. On the other hand, indicators related to corporate governance assessment are expected to be able to strengthen the effect of income smoothing on earnings response coefficient $[19,20]$.

H4: Corporate governance strengthens the influence of income smoothing on Earnings Response Coefficient

\section{E. Moderating Effect of Corporate Governance on the Relation Between Company Growth and Earnings Response Coefficient}

A fundamental problem is when investors have difficulty interpreting the incompleteness of information about the company's growth so that investors do not respond to the company's growth rate. When investors cannot interpret the information announced and the incompleteness related to information about the company's growth rate, the investor does not respond to the company's growth rate, meaning that the company's growth does not affect the value of ERC [8].

H5: Corporate governance strengthens the influence of corporate growth on ERC

\section{F. The Effect of Dividend Policy on Earnings Response Coefficient is Strengthened by Corporate Governance}

A management decision whether earnings generated from its business will be distributed to shareholders as a form of dividend distribution or earnings generated will be retained as a form of retained earnings. In accordance with the bird in-thehand theory that dividend policy has a positive influence on stock prices, because if the number of dividends distributed is greater, then the value of the company directly will be higher and vice versa. Because in general the dividend policy can indirectly reduce doubts for shareholders over the company's ability to make a profit. High corporate governance assessment is expected to be able to strengthen the effect of dividend policy on earnings response coefficient. Partially dividend 
policy has a positive effect on earnings response coefficient $[8,21]$.

H6: Corporate governance strengthens the effect of dividend policy on earnings response coefficient

\section{METHODS}

\section{A. Operational Definition and Measurement}

1) Dividend policy: Dividend policy is a management decision whether the company's earnings generated will be distributed to shareholders as dividends or the earnings obtained will be retained as a form of retained earnings for financing in the company's investment in the future [22]. DPR is a ratio that shows the ratio between the value of dividends per share with the value of earnings per share [23].

2) Company growth: Company growth is an increase or decrease in the total assets owned by the company. Company growth is calculated as a percentage change in assets in a particular year against the previous year [24]. The company's growth is measured by the level of increase in the company's net profit, which is the value of the company's net profit this year minus the value of the company's net profit last year, then divided by the value of the company's net profit last year.

3) Income smoothing: It is measured using a nominal scale. If an entity that practices earnings smoothing is given a value of 1 , while an entity that does not practice earnings smoothing is given a value of 0 . Eckel Index is proxied by a Coefficient Variation (CV) that uses sales variables (S) and net income variables (I). A company is said to do income smoothing practice if the coefficient of variation in sales changes is greater than the coefficient of variation in earnings changes and vice versa.

\section{Income smoothing index $=(C V \Delta I / C V \Delta S)$}

4) Earnings Response Coefficient (ERC): The formula to measure is: $\operatorname{CAR}_{\mathrm{i}[\mathrm{t}-3, \mathrm{t}+3]}=\beta_{0}+\beta_{1} \mathrm{UE}_{\mathrm{it}}+\varepsilon_{\mathrm{it}}$

Corporate governance: Corporate governance consists of a series of relationships between management, board of commissioners, board of directors, shareholders and other stakeholders [25]. Corporate governance is assessed using the ACG (ASEAN Corporate Governance) Scorecard method [26] that has been prepared by the ASEAN Capital Market Forum by using the assessment calculation of theme D and theme E. The list of ACGS disclosure check lists in this study uses a scorecard table developed by the ASEAN Capital Market Forum (ACMF) which began in 2011 consisting of 5 themes divided into 185 items of disclosure and used to find out how far the company discloses information about Corporate Governance, the weight of each theme as follows: a) Rights of Shareholders 10\% (26 question items), Shareholder Approval Approach 15\% (17 question items), Role of Stakeholders 10\% (21 question items), Disclosure and Transparency 25\% (42 question items), Board responsibility 40\% (79 question items).

The reference only uses 121 items from the theme D (Disclosure and Transactions) and the theme E (Board Responsibility) is based on Gandasari's research because these themes have the biggest weight of the existing theme, has a weight above $50 \%$ which is considered as a representative of all questions on ACGS. The disclosure of CG in the check list uses a score of 1 for the company that discloses and 0 if it does not disclose. Then the score is summed to find out the total CG disclosure of the company.

Based on these methods, the regression equation model formed from the seven variables is:

$$
\begin{aligned}
C A R=\beta_{0} & +\beta_{1} U E+\beta_{2} U E^{*} D P R+\beta_{3} U E^{*} G R O W T H+\beta_{4} U E^{*} I S \\
& +\beta_{5} U E^{*} G C G+\beta_{6} U E^{*} D P R^{*} G C G+ \\
& \beta_{7} U E^{*} G R O W T H^{*} G C G+\beta_{8} U E^{*} I S^{*} G C G+ \\
& \beta_{9} U E^{*} S I Z E+\beta_{10} U E^{*} D E R+\varepsilon_{i, t}
\end{aligned}
$$

Where: $\mathrm{CAR}=$ Cumulative abnormal return $(\mathrm{CARi},[\mathrm{t}-3, \mathrm{t}+3])$ company $i$ in year $t$ approximately 3 days from the publication of financial statements, $U E=$ Unexpected earnings of entity $i$ for the period $\mathrm{t}\left(\mathrm{UE}_{\mathrm{it}}\right), \mathrm{DPR}=$ Dividend Policy, GROWTH = Company Growth, IS= Income Smoothing, GCG= Corporate Governance, SIZE= Company Size, DER= Capital Structure

Control variables of this study are company size [27] and capital structure [28]. Measurement of company size (size) is the total value of company assets while Capital Structure is Debt to Equity Ratio (DER).

\section{RESULTS AND DISCUSSION}

The object of this research is manufacturing companies listed on the Indonesia Stock Exchange (BEI) in 2016 - 2018. The total samples were 129 manufacturing companies. The sample company was selected based on the following sample selection criteria:

TABLE I. DESCRIPTIVE STATISTICS (SOURCE: DATA PROCESSED BY SPSS 23)

\begin{tabular}{|l|c|l|l|l|l|}
\hline & $\mathbf{N}$ & Minimum & Maximum & Mean & Std. Deviation \\
\hline IS & $\mathbf{1 2 9}$ & $\mathbf{- 1 6 7 , 9 0}$ & $\mathbf{1 5 , 0 2}$ & $\mathbf{0 , 5 9 6 9}$ & $\mathbf{0 , 4 9 2 4 3}$ \\
\hline GROWTH & $\mathbf{1 2 9}$ & $\mathbf{- 0 , 9 3}$ & $\mathbf{2 4 , 6 3}$ & $\mathbf{0 , 4 8 3 2}$ & $\mathbf{2 , 5 6 9 4 1}$ \\
\hline DPR & 129 & 0,00 & 20,41 & 0,8128 & 2,26562 \\
\hline UE & 129 & $-0,31$ & 0,27 & 0,0029 & 0,06880 \\
\hline CG & 129 & 0,31 & 0,80 & 0,5149 & 0,08713 \\
\hline SIZE & 129 & 20,43 & 33,47 & 28,4795 & 2,17427 \\
\hline LEVRAGE & 129 & 0,00 & 4,19 & 0,7136 & 0,66240 \\
\hline CAR & 129 & $-0,10$ & 0,13 & 0,0036 & 0,03826 \\
\hline $\begin{array}{l}\text { Valid N } \\
\text { (Listwise) }\end{array}$ & 129 & & & & \\
\hline
\end{tabular}

Based on the results of descriptive statistical tests, it can be concluded that PT. Taisho Pharmaceutical Indonesia has the highest CAR value in 2018, PT. HM Sampoerna has the highest DPR value in 2017, PT. Indospring has the highest GROWTH value in 2016, PT. Lionmesh Prima has the highest IS in the study period, PT. Merck Indonesia has the highest EU value in 2018, PT. Indocement Tunggal Prakarsa has the largest CG value in 2016, PT. Astra International has the highest SIZE value in 2018 and PT. Indal Aluminum Industry had the highest LEVERAGE value in 2016.

TABLE II. T-TEST (SOURCE: DATA PROCESSED BY SPSS 23)

\begin{tabular}{|l|l|l|l|l|l|}
\hline \multicolumn{1}{|c|}{ Variable } & Prediction & \multicolumn{1}{c|}{ Beta } & t-stat & $\begin{array}{c}\text { Sig. } \\
(1-\text { tailed })\end{array}$ & Decision \\
\hline Constant & & 8,973 & 0,026 & 0,490 & \\
\hline UE & + & $-0,080$ & $-0,439$ & 0,330 & \\
\hline UE*IS & + & 0,956 & 1,932 & 0,028 & $\mathrm{H}_{1}$ accepted \\
\hline UE*GROWTH & + & $-0,213$ & $-1,007$ & 0,158 & $\mathrm{H}_{2}$ rejected \\
\hline UE*DPR & + & 0,501 & 1,031 & 0,152 & $\mathrm{H}_{3}$ rejected \\
\hline UE*G & + & 0,228 & 0,267 & 0,395 & \\
\hline UE*IS*CG & + & 1,838 & 1,990 & 0,024 & $\mathrm{H}_{4}$ accepted \\
\hline UE*GROWTH*CG & + & 0,439 & 1,007 & 0,158 & $\mathrm{H}_{5}$ rejected \\
\hline
\end{tabular}


Table 2. Cont.

\begin{tabular}{|c|c|c|c|c|c|}
\hline Variable & Prediction & Beta & t-stat & $\begin{array}{c}\text { Sig. } \\
\text { (1-tailed) }\end{array}$ & Decision \\
\hline UE*DPR*CG & + & $-1,196$ & $-1,233$ & 0,110 & $\mathrm{H}_{6}$ rejected \\
\hline UE*SIZE & & $-0,001$ & $-0,042$ & 0,483 & \\
\hline UE*DER & & 0,035 & 0,393 & 0,347 & \\
\hline Adjusted $\mathrm{R}^{2}$ & \multicolumn{5}{|l|}{0,038} \\
\hline F Test & \multicolumn{5}{|l|}{ Sig. $=0,007$} \\
\hline
\end{tabular}

\section{DISCUSSION}

The results showed that income smoothing had a positive effect on earnings response coefficient, seen from the one tail significant value of 0.028 . Thus, $\mathrm{H}_{1}$ is accepted. This indicates that the more frequent management of income smoothing actions, the more stable the level of earnings, so as it provides attractiveness to investors and also the value of earnings response coefficient represented by the cumulative abnormal return of the company.

This means that the existence of income smoothing measures will reflect the value of earnings that do not fluctuate significantly. This shows that investors will respond in detail to the company's earnings information that is relatively stable. The market reaction to companies that do income smoothing is different from companies that do not do income smoothing [14,29]. This result is contrary with [30-32].

Company growth does not affect the earnings response coefficient which is proxied by CAR with one significant value-tail 0,158 . Thus, $\mathrm{H}_{2}$ is rejected. Company growth can be proxied by signalling in the form of good news or bad news given by the company to investors. The signal is in the form of company earnings information, because profits generated by companies that have a high level of leverage will reduce the response of investors in receiving signals in the form of good news from the company, and vice versa if the company has a low level of leverage it will increase investor responses in receiving signals in the form of good news from the company. Growth factor was not statistically significant to ERC [33], this can happen because the motivation of investors in their investments is not to get long-term profits but to get capital gains.

Based on observations found that the dividend policy does not affect the earnings response coefficient which is proxied by CAR, seen from the one tail significant value of 0.152 . Thus, $\mathrm{H}_{3}$ is rejected. Dividend policy is basically a determination of how much portion of the earnings $s$ will be given to shareholders and which will be retained as retained earnings. It often happens that management has difficulty deciding whether to distribute dividends or will hold earnings for investment. The greater the retained earnings, the less the amount of profit allocated for dividend payments. The allocation of determining profits as retained earnings and dividend payments are the most important aspects of dividend policy.

Dividend policy does not affect earnings response coefficient because the application of conservative accounting will produce fluctuating earnings and earnings prediction power is low [34]. Earnings that have low predictive power are less useful in predicting future earnings so the resulting ERC will be low.

The results of the study which stated that dividend policy does not affect the value of the company support the irrelevance theory. The results of this study support research that found that there was no market reaction to the announcement of changes in dividend payments. The results of this study are consistent with dividend policy theory that dividend payments can also be translated as a negative signal which means that companies that increase dividend payments can be considered as companies that are no longer prospective in the future. Because dividends are basically the rest of the funds distributed as investment needs have been fulfilled. High dividends might indicate no prospective investments in the future. So that the dividend announcement does not affect the market reaction which ultimately does not affect the earnings response coefficient Besides that information about the dividends distributed by the company also seems to be less attention so that the company's ERC is not significant

One aspect that is used by management when preparing financial statements is the basis for business continuity, that the company will continue to operate and will not be liquidated. There is a positive influence between income smoothing actions with investor reactions that are assessed with earnings response coefficient. Hypothesis testing conducted in this study shows that corporate governance assessed by ACG strengthens the influence of the relationship between income smoothing and earnings response coefficient, with one significant valuetail 0,024 . Thus, $\mathrm{H}_{4}$ is accepted.

The results of this study are in line with previous research [14], where the market reaction to companies proxied by ERC that do income smoothing is different from companies that do not do income smoothing. Because the income smoothing action will reflect that company earnings does not fluctuate significantly. This shows that investors will respond in detail to the company's earnings information to earnings information that is relatively stable. Moreover, for companies that have implemented good governance may have more value in the eyes of investors as indicated by their positive reaction. Corporate governance (CG) is one of the ways companies increase investor confidence in company performance. So that investors will increase their desire in investing in companies.

The results of this study indicate that corporate governance assessed by ACG is not able to moderate the relationship between company growth and earnings response coefficient seen from the one tail significant value of 0.158 . Thus, $\mathrm{H}_{5}$ is rejected. This can be caused by the lack of awareness and initiative of manufacturing companies listed on the Indonesia Stock Exchange implemented CG well. So that CG has not been able to support the growth of companies that are valued by the level of corporate profits in influencing investor reactions assessed by earnings response coefficient.

The results of this study are in line with previous research [16], where company growth has no effect on earnings response coefficient. Due to the possibility there are other factors that influence including the persistence of earnings, risk, conservatism and others. The higher the ACG value of a company indicates that the company can be trusted by investors because it implements good corporate governance.

Unfortunately, the results of this study indicate that corporate governance assessed by ACG may not be able to moderate the relationship between dividend policy and earnings response coefficient seen from the one tail significant value of 0.110 [35]. Thus, $\mathrm{H}_{6}$ is rejected. This is due to the lack of awareness and initiative of manufacturing companies listed or listed on the Indonesia Stock Exchange in regards to the 
application of $\mathrm{CG}$ as it seems that $\mathrm{CG}$ is still limited to fulfil the requirement by the regulator. So that $\mathrm{CG}$ is not able to support the dividend policy which is assessed by using the ratio of the dividend pay-out ratio in influencing the reaction of investors who are assessed using the earnings response coefficient [7]. The results of this study are in line with previous research conducted [8], where the results of the study state that partially dividend policy has a positive effect on earnings response coefficient [21].

\section{CONCLUSIONS}

This study concludes that dividend policy and company growth do not affect earnings response coefficient, while Income smoothing has a positive effect on earnings response coefficient. Corporate governance may strengthen the effect of income smoothing on earnings response coefficient but it is not able to moderate the effect of dividend policy and company's growth on earnings response coefficient. Therefore, company should realize that investors do care about the company's earnings as they do not like the fluctuation of income. Thus, an effective way for the company in accordance with the expectations of its investors is income smoothing.

\section{REFERENCES}

[1] Otoritas Jasa Keuangan, Statistik Pasar Modal,2018.

[2] W.R. Scott, Financial Accounting Theory. 7th Edition. United States of America: Pearson Prentice Hall, 2015.

[3] K.U. Sandi, "Faktor - faktor Yang Mempengaruhi Earnings Response Coefficient," Accounting Analysis Journal, vol. 2, no. 3, 2013.

[4] V. Herawaty, "The effect of environmental performance and accounting characteristics to earnings informativeness," IOP Conf. Series: Earth and Environmental Science, 2018.

[5] S. Suprantiningrum, "Pengaruh Dimensi Kecerdasan Emosional Mahasiswa Akuntansi terhadap Tingkat Pemahaman Akuntansi," Jurnal Akuntansi, vol. 27, no. 1, 2013.

[6] R. Ball and P. Brown, "An Empirical Evaluation of Accounting Income Numbers," Journals of Accounting Research, vol. 6, pp. 159-178, 1968.

[7] I. Adonis, Pengaruh Tingkat Kesehatan Perusahaan, dan Opini Going Concern Terhadap Earnings Response Coefficient dengan Good Corporate Governance Sebagai Variabel Moderasi, Fakultas Ekonomi dan Bisnis, Universitas Trisakti, 2018.

[8] Y. Ningsih, Pengaruh Free Cash Flow Terhadap Hubungan Antara Pertumbuhan Perusahaan, Ukuran Perusahaan dan Kebijakan Dividen dengan Earnings Response Coefficient Pada Perusahaan Yang Terdaftar di Jakarta Islamic Index. UIN Sunan Kalijaga. Yogyakarta, 2016.

[9] P.K. Chaney and D.C. Jeter, "The effect of Size on the Magnitude of Long Window Earnings Response Coefficients," Contemporary Accounting Research, vol. 8, no. 2, pp. 540-560, 1991.

[10] G. Ginting, "Analisis Pengaruh Ukuran Perusahaan, Profitabilitas, Timeliness, dan Struktur Modal Terhadap Earnings Response Coefficient Pada Perusahaan Manufaktur yang Terdaftar di Bursa Efek Indonesia 2012-2014,” Jakpi, vol. 05, no. 01, 2017.

[11] J. Hartono, Teori Portofolio dan Analisis Investasi. Edisi Kedelapan. Yogyakarta: BPFE-Yogyakarta, 2013.

[12] M.C. Jensen and W. Meckling, "Theory of the Firm: Managerial Behavior, Agency Costs and Ownership Structure," Journal of Financial Economics, vol. 3, no. 5, pp. 305-360, 1976.

[13] E.F. Fama, "Efficient market: A review of theory and empirical work," Journal of Finance, vol. 25, no. 2, pp. 383-417, 1970.
[14] R.T.M. Sirait, "Pengaruh Praktik Perataan Laba Terhadap Earnings Response Coefficient Pada Perusahaan Manufaktur di Bursa Efek Indonesia,” Jurnal Ilmiah Integritas, vol. 2, no. 1, 2016.

[15] S.W. Agustiningsih, "Peran income smoothing dalammeningkatkanearnings informativeness," Jurnal Akuntansi dan Bisnis, vol. 14, no. 2, 2014.

[16] K.U. Sandi, "Faktor-faktor Yang Mempengaruhi Earnings Response Coefficient," Accounting Analysis Journal, vol. 2, no. 3, 2013.

[17] C. Lestari, Faktor-faktor yang Mempengaruhi Earnings Response Coefficient pada Perusahaan Manufaktur yang Terdaftar di Daftar Efek Syariah Periode 2012-2014. Fakultas Ekonomi dan Bisnis Islam, Universitas Islam Negeri Sunan Kalijaga, Yogyakarta, 2016.

[18] M.J. Gordon, "Dividends, Earnings, and Stock Prices," The Review of Economics and Statistics, vol. 41, no. 2, pp. 99-105, 1959.

[19] P. Mutiara, "Pengaruh Corporate Governance dan Pengungkapan CSR Terhadap Earnings Response Coefficient (Perusahaan Manufaktur tahun 2015)," Forum Keuangan dan Bisnis Indonesia, vol. 6, pp. 95-116, 2017.

[20] M. Nisrina and V. Herawaty, "Peran Intellectual Capital Disclosure sebagai Pemoderasi Pengaruh Perataan Laba, Good corporate governance, Kesempatan Bertumbuh, Persistensi Laba dan Leverage Terhadap Keinformatifan Laba. Universitas Trisakti," Jurnal TEKUN vol. VII, no. 01, pp. 118-146, 2016.

[21] D. Husiano and S. Suratno, "Analisis Pengaruh Beta, Leverage, Dividend Payout Ratio, dan Earnings Persistence terhadap Earnings Response Coeffiient pada Indeks Kompas 100," Jurnal Riset Akuntansi dan Perpajakan (JRAP), vol. 1, no. 2, pp. 121-135, 2014.

[22] S. Sartono, Manajemen Keuangan Teori dan Aplikasi. Edisi Empat, Yogyakarta: BPFE, 2008.

[23] I.M. Sudana, Manajemen Keuangan Perusahaan. Edisi Kedua. Jakarta: Erlangga, 2015.

[24] S. Suprantiningrum, "Pengaruh Dimensi Kecerdasan Emosional Mahasiswa Akuntansi terhadap Tingkat Pemahaman Akuntansi," Jurnal Akuntansi, vol. 27, no. 1, 2013.

[25] OECD, G20/OECD Principles of Corporate Governance. Paris: OECD Publishing, 2015.

[26] D. Justina and A.J. Simamora, "Moderating Role of Firms' Rank in ASEAN Corporate Governance Scorecard on Effect of Foreign Ownership on Firm Value," Jurnal Siasat Bisnis, vol. 22, no. 2, pp. 141160, 2017.

[27] R. Rofika, Faktor - faktor Yang Mempengaruhi Struktur Modal Pada Perusahaan Industri Farmasi Yang Terdaftar di BEI, 2011.

[28] K. Kasmir, Analisis Laporan Keuangan. Jakarta: Raja Grafindo Persada, 2016.

[29] C.S.A. Cheng and S. Li, "Does income smoothing improve earnings informativeness? Acomparisonbetween the US and China markets," China Accounting and Finance Review, vol. 16, no. 2, pp. 128-147, 2014.

[30] A. Firmansyah, "Pengaruh Income Smoothing dan Real Earnings Management Terhadap Keinformatifan Laba," Jurnal Online Insan Akuntan, vol. 2, no. 2, pp. 175-188, 2017.

[31] D. Istifarda, "Pengaruh Income Smoothing Terhadap Earnings Response Pada Perusahaan Manufaktur di Bursa Efek Indonesia," Artikel Ilmiah Mahasiswa. Fakultas Ekonomi, Universitas Jember, 2015.

[32] S.N. Nazar, "Does income smoothing improve informavatiness of stock prices?" Jurnal Ilmiah Econosains, vol. 15, no. 2, pp. 225-239, 2017.

[33] L. Fitri, "Pengaruh Ukuran Perusahaan, Kesempatan Bertumbuh, Dan Profitabilitas Terhadap Earnings Response Coefficient (Studi Empiris Pada Perusahaan Manufaktur yang Terdaftar Di Bursa Efek Indonesia (BEI) Tahun 2008-2011)," Jurnal Akuntansi, vol. 1, no. 3, 2013.

[34] N. Nofianti, "Pengaruh Struktur Modal, Ukuran Perusahaan, Dan Kebiakan Dividen Terhadap Koefisien Respon Laba,” Jurnal Etikonomi, vol. 13, no. 2, 2014.

[35] J.D. Ma'rifah, C.S. Nurrachma, R.A. Pranataningrum and V. Herawaty, "Good Corporate Governance Dan Earning Response Coefficient (Intellectual Capital Disclosure Sebagai Pemoderasi Pada Perusahaan Manufaktur Yang Terdaftar Di BEI Tahun 2015-2017,"' Prosiding Seminar Nasional Pakar, pp. 2-61, 2019. 